\title{
Experimental Organism Brunner's Gland Carcinoma
}

National Cancer Institute

\section{Source}

National Cancer Institute. Experimental Organism Brunner's Gland Carcinoma. NCI

Thesaurus. Code C156611.

A malignant epithelial neoplasm arising from the cells of the Brunner's gland with

desmoplasia being the most dominant feature along with a diminished or lost glandular structure. (INHAND) 